\title{
ACD Gene Mutation
}

National Cancer Institute

\section{Source}

National Cancer Institute. ACD Gene Mutation. NCI Thesaurus. Code C152088.

A change in the nucleotide sequence of the ACD gene. 